\title{
Nitrogen Application Modifies the Seed and Oil Yields and Fatty Acid Composition of Nicotiana tabacum
}

\author{
Yingchao Lin, Dejun Kong, Zhihong Wang, Yi Chen, Zhixiao Yang, \\ Chun Wu, Hui Yang, and Lili Chen \\ Guizhou Academy of Tobacco Science, Guiyang, 550081, China
}

Additional index words. alternative use, nitrogen, seed oil, tobacco

\begin{abstract}
Tobacco is traditionally an industrial crop that is used for manufacturing cigarettes. However, due to health concerns and global tobacco control movements, alternative uses of tobacco are urgently needed to support tobacco farmers and vendors. Tobacco is also an oilseed crop with an oil yield ranging from $30 \%$ to 40 of its dry weight. However, there is still no information on the effects of nitrogen application on tobacco seed yield and seed oil production. The objective of this study was to evaluate the effects of $\mathrm{N}$ fertilization $\left(90,120,150\right.$, and $\left.180 \mathrm{~kg} \cdot \mathrm{ha}^{-1} \mathrm{~N}\right)$ on the seed yield, oil content, fatty acid composition, and seed germination characteristics of tobacco plants at two locations. The results showed that applying increasing amounts of $N$ to tobacco plants significantly increased their total seed yields and oil content. Nitrogen application also modified the fatty acid composition of the seed oil, as more unsaturated fatty acids were produced under the increasing $\mathbf{N}$ application rate treatments than under the control. Moreover, increasing the $\mathbf{N}$ application rate generally significantly increased the yields of individual fatty acids as well. Nevertheless, the increased seed oil content and altered fatty acid composition did not affect seed germination traits, as the seed germination potential and rate showed no obvious change among treatments or the control. The height and size of the tobacco plants also increased with the increasing $N$ application rate, which would be beneficial for increasing biomass production for bioenergy. This study shows for the first time the feasibility of increasing the seed and oil yields and modifying the fatty acid composition of tobacco plants by increasing $\mathbf{N}$ addition.
\end{abstract}

Tobacco is a perennial plant in the Solanaceae family that has been grown as an important cash crop for more than 350 years in many countries around the world. Although the genus includes more than 65 species, Nicotiana tabacum L. (common tobacco) is the only commercially cultivated and economically important species. As a cash crop in China that has a strong impact on the national economy, the principal production areas of tobacco are concentrated in remote rural areas with less developed economies, such as Guizhou and Yunnan. Essential poverty relief and increased incomes come from tobacco planting in such areas (Lin et al., 2018).

However, due to health concerns about cigarettes and the global tobacco control movements, the tobacco acreage in such areas is under the threat of being decreased. Problems

\footnotetext{
Received for publication 27 July 2020. Accepted for publication 28 Aug. 2020.

Published online 26 October 2020.

We are grateful to Dr Kai Cai for assistance in analyzing fatty acid content. This study was supported by the Science and Technology Foundation of Guizhou Province, China ([2020]1Y106), and the Science and Technology Foundation of Guizhou Tobacco (201801, 201805, 2020XM02).

Y.L. is the correspondence author. E-mail: linyingchao@outlook.com.

This is an open access article distributed under the CC BY-NC-ND license (https://creativecommons. org/licenses/by-nc-nd/4.0/).
}

will arise from this; for example, farmers who have developed tobacco cultivation skills and invested many economic resources in transformation facilities will be underused, and tobacco-cropping machinery producers will have to cope with market loss and eventually convert their facilities for new mechanical production as well. Thus, an alternative use of tobacco for other products is urgently needed to reorganize a sustainable local economy in these traditional tobacco-growing areas.

The tobacco plant can offer a wide range of alternative applications, such as producing biogas, a generalized biofuel that is widely accepted, by placing green tobacco tissues (stems and leaves) inside an anaerobic digester. Biofuel for transport represents the major portion of worldwide bioenergy production, and food crops with high sugar or starch contents are some of the main sources of renewable raw material (Ho et al., 2014). However, this practice has been called into question because it creates competition with food crops and impacts food supplies and prices. Therefore, novel nonfood or nonfeed plant resources for biofuel and bioenergy production need to be developed. Tobacco is a large plant with high biomass production, and it typically experiences significantly less herbivore damage than other agricultural crops (Yuan 2020); therefore, tobacco is an ideal plant for such bioenergy production and can be genetically engineered to produce high-density biofuels and engineering en- zymes for novel functions in biomass conversion (Andrianov et al., 2010; Vanhercke et al., 2014).

Tobacco seeds, available as an unused byproduct of commercial leaf production in many countries around the world, can be a valuable source of natural products with biological activity and have been considered a source of glycerides as well as biodiesel (Frega et al., 1991; Popova et al., 2018; Xie et al., 2011). Specifically, tobacco is an oilseed crop with an oil yield ranging from $30 \%$ to $40 \%$ of seed dry weight, which is higher than that of some other common oilseed crops, such as corn (3\% to $5 \%)$, cotton $(16 \%)$, soybean $(18 \%)$, and olive $(18 \%$ to $25 \%)$ and close to that of mustard (37\% to $39 \%$ ), canola ( $37 \%$ to $41 \%)$, sunflower $(25 \%$ to $47 \%)$, and safflower (38\% to $48 \%)$ (Elbadawy et al., 2016; Giannelos et al., 2002; Methamem et al., 2015; Popova et al., 2018; Zheljazkov et al., 2011, 2012, 2013); this highlights the potential of tobacco seeds as a source of industrial and edible oils (Giannelos et al., 2002; Usta 2005).

Generally, it has been shown that the yield of common tobacco seed oil and its fatty acid profile are influenced by genotype, climatic conditions, and other factors, such as water and fertilizer application (Grisan et al., 2016; Mohammad and Tahir, 2014; Rossi et al., 2013). Among the nutrients supplied to the crops, $\mathrm{N}$ is frequently considered the key limiting factor responsible for lower productivity, and its incorrect use often leads to low nitrogen use efficiency and serious $\mathrm{N}$ loss, which in turn lead to polluting the environment via emission of greenhouse gases and leaching of nitrate into groundwater (Campiglia et al., 2011; Jensen and Hauggaard-Nielsen, 2003; Shi and Yu, 2008). Thus, developing or improving $\mathrm{N}$ agricultural management practices to reduce environment risk and enhance $\mathrm{N}$ use efficiency is of vital importance for sustainable agriculture (Campiglia et al., 2011; Kuo and Jellum, 2002; Sainju and Singh, 2008).

As demonstrated previously, $\mathrm{N}$ application can affect the seed yield, oil content, and composition of other crops such as wheat, sunflower, and winter mustard ( $\mathrm{Li}$ et al., 2019; Zheljazkov et al., 2009). Significant differences in the fatty acid composition were observed under different $\mathrm{N}$ fertilization in walnut kernels (cv. Chandler) (Verardo et al., 2013). Moreover, the response of tobacco plants, particularly leaves, to different nutrients, including $\mathrm{N}$, has been extensively studied (Lin et al., 2017). However, there is no research on the effects of $\mathrm{N}$ on tobacco seed yields or fatty acid composition. In the present study, to investigate the effects of $\mathrm{N}$ application on the seed and oil yields and fatty acid composition of Nicotiana Tabacum, field experiments were conducted at two independent study sites in 2 years. The results will provide more information on the cultivation of tobacco for seed oil production.

\section{Materials and Methods}

Study site and field experimental design. The study was conducted in Fuquan (lat. 
$26^{\circ} 44^{\prime} 34^{\prime \prime} \mathrm{N}$, long. $107^{\circ} 30^{\prime} 1^{\prime \prime} \mathrm{E}$ ) in 2016, at an altitude of $1020 \mathrm{~m}$, and Qingzhen (lat. $26^{\circ} 31^{\prime} 27^{\prime \prime} \mathrm{N}$, long. $106^{\circ} 21^{\prime} 16^{\prime \prime} \mathrm{E}$ ) in 2017 , at an altitude of $1280 \mathrm{~m}$, in Guizhou, China. Tenday average temperature and 10-day precipitation records from April to October and the soil properties $(0-20 \mathrm{~cm})$ at the two study sites are presented in Fig. 1 and Table 1, respectively.

Seeds of Nicotiana tabacum L. cv. GZ21 were sown in an open greenhouse on $25 \mathrm{Feb}$. 2016 and 20 Feb. 2017 on transplanting disks as described previously in detail (Lin et al., 2018). For the field experiment, a series of agricultural operations, including turning up the soil, ridging, plastic mulching, and planting hole preparation, were carried out as described previously in detail (Lin et al., 2015, 2018). Seedlings were transplanted into the test plots $(15 \times 7 \mathrm{~m})$ on 2 May 2016 and 25 Apr. 2017. For the nitrogen applications, different nitrogen rates, including 1) 90 $\mathrm{kg} \cdot \mathrm{ha}^{-1} \mathrm{~N}$ (control), 2) $\left.120 \mathrm{~kg} \cdot \mathrm{ha}^{-1} \mathrm{~N}, 3\right) 150$ $\mathrm{kg} \cdot \mathrm{ha}^{-1} \mathrm{~N}$, and 4) $180 \mathrm{~kg} \cdot \mathrm{ha}^{-1} \mathrm{~N}$, were applied as a special compound fertilizer for flue-cured tobacco $\left(\mathrm{N}: \mathrm{P}_{2} \mathrm{O}_{5}: \mathrm{K}_{2} \mathrm{O}, 10: 10: 24\right.$; Qiannan Jinfu Company Limited, Guizhou, China) in two separate doses; $60 \%$ was applied as a base before ridging, and the remaining $40 \%$ was applied $45 \mathrm{~d}$ after transplanting to the test plots. All treatments had three replications, and a completely randomized block design was used.

Assays of plant growth. Plant height was measured by the distance from the stem base to the first capsule. Stem diameter was measured by the stem circumference at one-third of the plant height. Leaf area was measured using a fresh leaf area meter (AM 300; ADC Bioscientific Ltd., Hoddesdon, UK) as described previously (Lin et al., 2018). Nodal distance was measured by the average length between five leaves up and down from onethird of the plant height.

Assays of thousand-seed weight, total seed yield, and fatty acid yields. Capsules were harvested at maturity and dried to a constant weight. The weight of 1000 seeds was measured as the thousand-seed weight. For the total seed yield assay, the seed weights of all test plots with different nitrogen rates
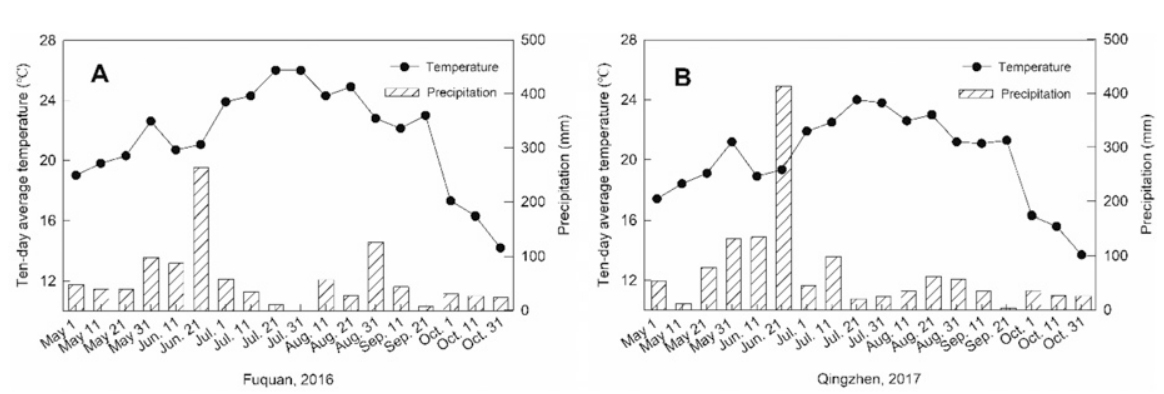

Fig. 1. Precipitation from April to October at (A) Fuquan in 2016 and (B) Qingzhen in 2017. were separately surveyed to calculate the total seed yield as the seed yield / plot $\times 10,000 \mathrm{~m}^{2}$ (1 ha) / $(15 \times 7) \mathrm{m}^{2}$. The fatty acid yields were calculated as follows: fatty acid yield $=$ fatty acid content $(\%) \times$ total seed yield.

Analysis of seed oil content and fatty acid composition. The Soxhlet extraction method was employed to determine the seed oil content. Dry seeds were ground and placed in the Soxhlet extractor, and petroleum ether, heating reflux, and solvent extract were added. The weight lost after extraction is the seed oil content. The extracted seed oil $(20 \mu \mathrm{L})$ was added to benzene:petroleum ether $(1: 1)$ and then mixed with $\mathrm{NaOH}-m e t h a n o l\left(0.4 \mathrm{~mol} \cdot \mathrm{L}^{-1}\right)$ after dissolution. After incubation for $1 \mathrm{~h}$, distilled water was added to the mixture. The supernatant was collected after solution stratification and filtered through an organic membrane $(0.45 \mu \mathrm{m})$. The sample $(1 \mathrm{~mL})$ was transferred into a vial. Gas chromatography analysis was conducted on an Agilent HP 6890 (Agilent Technologies, Santa Clara, CA) equipped with a flame ionization detector and a DB-23 capillary column $(30 \mathrm{~m} \times 0.25 \mathrm{~mm}$; $\mathrm{J} \& \mathrm{~W}$ Scientific, Folsom, CA). The injector and detector temperatures were both set at $230{ }^{\circ} \mathrm{C}$. The temperature program was as follows: $130{ }^{\circ} \mathrm{C}$ for $1 \mathrm{~min}$, increased to $185{ }^{\circ} \mathrm{C}$ at 5 ${ }^{\circ} \mathrm{C} \cdot \mathrm{min}^{-1}$, then increased to $220{ }^{\circ} \mathrm{C}$ at 10 ${ }^{\circ} \mathrm{C} \cdot \mathrm{min}^{-1}$, and finally held for $2 \mathrm{~min}$ for a total run time of $19.5 \mathrm{~min}$. Data were collected and analyzed using Agilent Chemstation software (Agilent, Palo Alto, CA).

Assays for seed germination potential and germination rate. For the germination rate assays, at least 100 seeds from plants grown under the different $\mathrm{N}$ rates were sown randomly on separate plates $(9 \mathrm{~cm})$ with saturated cotton and filter paper, and the cotton and filter paper were kept wet during the whole experiment. There were three replicates of each seed treatment. The seeds were then cultivated at $23{ }^{\circ} \mathrm{C}$ under a 12 -h light/ 12 -h dark cycle and a light intensity of $\approx 220 \mu \mathrm{mol} \cdot \mu \mathrm{mol}^{-2} \cdot \mathrm{s}^{-1}$ as described previously (Lin et al., 2013). Germination was defined as the emergence of the radicle from the seeds. The germinated seeds were counted after 7 and $14 \mathrm{~d}$ of treatment. The seed germination potential and seed germination rate were calculated as follows:

$$
\begin{gathered}
\text { Seed germination potential }(\%) \\
=\text { Number of germinated seeds } s_{7 d} / \\
\text { Number of total test seeds } \times 100 \\
\text { Seed germination rate }(\%) \\
=\text { Number of germinated seeds }{ }_{14 d} / \\
\text { Number of total test seeds } \times 100
\end{gathered}
$$

Statistical analysis. Statistical analysis was performed using SPSS-17 statistical software. The data presented here are means of the values with SE. The effects of study sites and $\mathrm{N}$ rates and their interaction in seed yield, seed oil content, and fatty acid compositions were evaluated using two-way analysis of variance. Differences between treatments were separated by the least significant difference test at a $0.05 P$ level. The figures were created in Sigma Plot 10.0 (Systat Software, Inc., Palo Alto, CA).

\section{Results}

Effects of $N$ application on total seed yield and seed oil content. Both the thousand-seed weight and the seed yield were significantly affected by the $\mathrm{N}$ rate, and the thousand-seed weight reached its highest value in the 150 $\mathrm{kg} \cdot \mathrm{ha}^{-1} \mathrm{~N}$ treatment at the two locations. Although the total seed yield was higher in the $180 \mathrm{~kg} \cdot \mathrm{ha}^{-1} \mathrm{~N}$ treatment, no significant difference were detected compared with that in the $120 \mathrm{~kg} \cdot \mathrm{ha}^{-1} \mathrm{~N}$ treatment (Table 2).

The effect of $\mathrm{N}$ application on seed oil content was significant at both Fuquan and Qingzhen, and seed oil content reached its highest values of $38.70 \%$ and $39.81 \%$ in the 150 $\mathrm{kg} \cdot \mathrm{N} \cdot \mathrm{ha}^{-1}$ treatment at the two locations, respectively (Table 3 ). There were no significant differences in seed oil content between the 150 and $180 \mathrm{~kg} \cdot \mathrm{ha}^{-1} \mathrm{~N}$ treatments at the two study sites.

Effects of $N$ application on the fatty acid composition and yield of tobacco seed oil. Increased $\mathrm{N}$ application had only a minor effect on the fatty acid composition of the tobacco seed oil except in terms of the linolenic acid content, which increased significantly at higher $\mathrm{N}$ rates $(120,150$, and 180 $\mathrm{kg} \cdot \mathrm{ha}^{-1} \mathrm{~N}$ ) compared with those in the control at both the Fuquan and Qingzhen sites (Table 4). Moreover, the linolenic acid con-

\begin{tabular}{|c|c|c|c|c|c|c|c|c|}
\hline & $\mathrm{pH}$ & $\begin{array}{c}\text { Organic } \\
\text { matter }\left(\mathrm{g} \cdot \mathrm{kg}^{-1}\right)\end{array}$ & $\begin{array}{l}\text { Total N } \\
\left(\mathrm{g} \cdot \mathrm{kg}^{-1}\right)\end{array}$ & 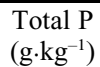 & Total K $\left(\mathrm{g} \cdot \mathrm{kg}^{-1}\right)$ & $\begin{array}{l}\text { Hydrolytic N } \\
\left(\mathrm{mg} \cdot \mathrm{kg}^{-1}\right)\end{array}$ & $\begin{array}{c}\text { Available P } \\
\left(\mathrm{mg} \cdot \mathrm{kg}^{-1}\right)\end{array}$ & $\begin{array}{c}\text { Available K } \\
\left(\mathrm{mg} \cdot \mathrm{kg}^{-1}\right)\end{array}$ \\
\hline Qingzhen & 6.53 & 19.29 & 1.32 & 0.56 & 15.20 & 128.32 & 14.03 & 161.57 \\
\hline
\end{tabular}
centrations were the highest in the $150 \mathrm{~kg} \cdot \mathrm{ha}^{-1}$ $\mathrm{N}$ treatment at the two locations (Table 4).

As a function of the seed yield and the concentrations of the individual fatty acids in

Table 1. Soil properties at the two experimental sites. 
the oil, the yield of palmitic, stearic, oleic, linoleic, and linolenic fatty acids generally increased significantly at higher $\mathrm{N}$ rates (120 or $150 \mathrm{~kg} \cdot \mathrm{ha}^{-1} \mathrm{~N}$ ) compared with that in the control (Table 5). Generally, the highest yield of fatty acids in the two locations was except for oleic acid at Fuquan and palmitic acid at Qingzhen, both of which achieved the highest yield in the $180 \mathrm{~kg} \cdot \mathrm{ha}^{-1} \mathrm{~N}$ treatment (Table 5). yield of the individual fatty acids in the tobacco seed oil. The correlation coefficients between the $\mathrm{N}$ rate and seed yield, seed oil content, the yields of the individual fatty acids in the tobacco seed oil are shown in Table 6. As the values indicate, significant correlation was detected with the seed yield and seed oil content and $\mathrm{N}$ rates. The $\mathrm{N}$ rate also had a significant positive correlation with the yields of palmitic, stearic, oleic, linoleic, and unsaturated fatty acids. On the other hand, yields of palmitic, oleic, linolenic, and unsaturated fatty acid were also significantly affected by environmental conditions of study sites (Table 6).

Seed germination potential and germination rate of seeds from the tobacco plants grown at different $N$ rates. No significant differences were detected among seeds originating from the four $\mathrm{N}$ rates at either study site except that both the seed germination potential and the germination rate of seeds from Qingzhen were slightly lower than those of seeds from Fuquan (Table 7). achieved in the $150 \mathrm{~kg} \cdot \mathrm{ha}^{-1} \mathrm{~N}$ treatment,

Relationships between the $N$ rate and the

Morphological traits of the tobacco plants under different $N$ rates. Compared with that under the control treatment, increasing the $\mathrm{N}$ rate significantly increased the plant height of the tobacco plants at both study sites (Table 8). The other three morphological traits, namely, stem diameter, leaf area and nodal distance, were all increased significantly by the increasing $\mathrm{N}$ rates. However, applying $180 \mathrm{~kg} \cdot \mathrm{ha}^{-1} \mathrm{~N}$ did not increase these traits significantly above what was obtained at $120 \mathrm{~kg} \cdot \mathrm{ha}^{-1} \mathrm{~N}$ (Table 8).

\section{Discussion}

In this study, to identify the effects of nitrogen application on the seed oil production of tobacco plants, the total seed yield, oil content, and fatty acid composition of the tobacco seed oil developed under different $\mathrm{N}$ application rates were analyzed at two independent study sites in two years. The results clearly showed that the total seed yield, seed oil content and yield of individual fatty acids as well as that the plant biomass were increased significantly by increasing $\mathrm{N}$ application rates. Nevertheless, $\mathrm{N}$ fertilization did not affect seed germination characteristics such as germination potential and germination rate at both two study sites.

As the results show, total seed yield was increased significantly by an increase in $\mathrm{N}$ rates at both study sites, which was consistent with previous studies in tobacco, as well as some other crops, such as corn, rice, wheat, and soybean (Cheng et al., 2015; Gediya et al., 2008; Li et al., 2019; Zhang et al., 2014, 2018, 2019). This

Table 2. Mean thousand-seed weight and seed yield under four $\mathrm{N}$ rates at the two locations.

\begin{tabular}{llcccc}
\hline & \multicolumn{2}{c}{ Fuquan 2016} & & \multicolumn{2}{c}{ Qingzhen 2017} \\
\cline { 2 - 3 } $\begin{array}{l}\text { N rate } \\
\left(\mathrm{kg} \cdot \mathrm{ha}^{-1}\right)\end{array}$ & $\begin{array}{c}\text { Thousand-seed } \\
\text { wt }(\mathrm{mg})\end{array}$ & $\begin{array}{c}\text { Seed yield } \\
\left(\mathrm{kg} \cdot \mathrm{ha}^{-1}\right)\end{array}$ & & $\begin{array}{c}\text { Thousand-seed } \\
\text { wt }(\mathrm{mg})\end{array}$ & $\begin{array}{c}\text { Seed yield } \\
\left(\mathrm{kg} \cdot \mathrm{ha}{ }^{-1}\right)\end{array}$ \\
\hline 90 & $83.03+0.33 \mathrm{c}^{\mathrm{z}}$ & $153.5 \pm 3.59 \mathrm{~b}$ & & $82.58+0.33 \mathrm{~b}$ & $158.24 \pm 3.19 \mathrm{~b}$ \\
120 & $85.43 \pm 0.13 \mathrm{bc}$ & $182.5 \pm 11.83 \mathrm{a}$ & & $84.25 \pm 0.13 \mathrm{~b}$ & $187.32 \pm 7.38 \mathrm{a}$ \\
150 & $90.20 \pm 0.10 \mathrm{a}$ & $195.95 \pm 7.16 \mathrm{a}$ & & $89.92 \pm 0.10 \mathrm{a}$ & $193.64 \pm 5.18 \mathrm{a}$ \\
180 & $87.47 \pm 0.23 \mathrm{~b}$ & $199.75 \pm 9.55 \mathrm{a}$ & & $87.33 \pm 0.23 \mathrm{a}$ & $197.84 \pm 13.22 \mathrm{a}$ \\
\hline
\end{tabular}

${ }^{\mathrm{z}}$ Different letters within a column denote significant differences between treatments at $P<0.05$.

Table 3. Content of oil in the seeds of the tobacco plants under four $\mathrm{N}$ rates at the two locations.

\begin{tabular}{lcc}
\hline & \multicolumn{2}{c}{ Seed oil content (\%) } \\
\cline { 2 - 3 } $\mathrm{N}$ rate $\left(\mathrm{kg} \cdot \mathrm{ha}^{-1}\right)$ & Fuquan 2016 & Qingzhen 2017 \\
\hline 90 & $31.46+1.58 \mathrm{c}^{\mathrm{z}}$ & $33.29 \pm 1.38 \mathrm{~b}$ \\
120 & $35.21+1.37 \mathrm{~b}$ & $35.72 \pm 2.01 \mathrm{~b}$ \\
150 & $38.70 \pm 1.40 \mathrm{a}$ & $39.81 \pm 1.13 \mathrm{a}$ \\
180 & $37.47 \pm 1.69 \mathrm{a}$ & $38.04 \pm 1.71 \mathrm{a}$ \\
\hline
\end{tabular}

${ }^{\mathrm{z}}$ Different letters within the column denote significant differences between treatments at $P<0.05$. might partly result from the increased absolute weight of the seeds (thousand-seed weight) under the increased $\mathrm{N}$ rate treatment, as the results indicated (Table 2). As reported in some other crops, such as corn, rice, wheat, and soybean, $\mathrm{N}$ application has substantial impacts on seed size and output (Li et al., 2019; Shen et al., 2017; Xu et al., 2018; Yong et al., 2018; Zhang et al., 2019). No significant differences were detected for the parameters of total seed yield and thousand-seed weight at the two locations under the same $\mathrm{N}$ rates, indicating that these characteristics of tobacco plants, at least in part, have a wide tolerance of and adaptability to different ecological and meteorological conditions.

Maximizing the total seed and oil yields of tobacco plants is preferable for its alternative applications. Thus, we then investigated the effects of $\mathrm{N}$ application rates on seed oil content in the present study. In accordance with previous reports that $\mathrm{N}$ application to biofuel or biodiesel crops has major implications for the profitability of biofuel feedstock systems (Zheljazkov et al., 2012), our results show that the seed oil content can be significantly increased by applying more $\mathrm{N}$ : the seed oil content in the 120,180 , and 150 $\mathrm{kg} \cdot \mathrm{ha}^{-1} \mathrm{~N}$ treatments increased significantly compared with that in the control at both Fuquan and Qingzhen (Table 3).

Five main fatty acids were identified that constituted nearly $100 \%$ of the total oil content. Increases in individual fatty acid yields in the seed oil at the two study sites were detected in the 120,180 , and $150 \mathrm{~kg} \cdot \mathrm{ha}^{-1} \mathrm{~N}$ treatments, which might be due to the increased total seed yield (Table 2). Nitrogen fertilization also affected fatty acid composition, and linoleic acid was the main fatty acid present in walnut kernels. $\mathrm{N}$ fertilization reduced the oleic acid content relative to the control. High amounts of $\mathrm{N}$ increased the linoleic acid content and reduced the linolenic acid content (Verardo et al., 2013). The different response of fatty acid composition to $\mathrm{N}$ fertilization between Woody and herbaceous plants suggests the complex process of regulation. However, both seed oil content and several fatty acid yields declined in the $180 \mathrm{~kg} \cdot \mathrm{ha}^{-1}$ $\mathrm{N}$ treatments compared with those of 150 $\mathrm{kg} \cdot \mathrm{ha}^{-1} \mathrm{~N}$ treatments, indicating that they are sensitive to nutrients supply. High rates of $\mathrm{N}$ application might result to more vigorous vegetative growth, which takes up more allocation that is originally the seed nutrition, for example. Moreover, the significant positive correlations shown among seed yield, seed oil content, and palmitic, stearic, oleic, linoleic, linolenic, and unsaturated acids with $\mathrm{N}$ rate

Table 4. Content of fatty acids in the seed oils of the tobacco plants under four $\mathrm{N}$ rates at the two locations.

\begin{tabular}{|c|c|c|c|c|c|c|c|}
\hline Location & $\mathrm{N}$ rate $\left(\mathrm{kg} \cdot \mathrm{ha}^{-1}\right)$ & Palmitic 16:0 (\%) & Stearic 18:0 (\%) & Oleic 18:1 (\%) & Linoleic 18:2 (\%) & Linolenic 18:3 (\%) & Unsaturated fatty acid (\%) \\
\hline \multirow{3}{*}{ Fuquan 2016} & 90 & $8.37 \pm 0.81 \mathrm{a}^{\mathrm{z}}$ & $3.84 \pm 0.20 \mathrm{a}$ & $12.84 \pm 0.92 \mathrm{a}$ & $73.71 \pm 8.76 \mathrm{a}$ & $0.73 \pm 0.11 \mathrm{c}$ & $87.79 \pm 0.43 \mathrm{a}$ \\
\hline & 150 & $8.36 \pm 0.46 \mathrm{a}$ & $4.04 \pm 0.62 \mathrm{a}$ & $12.85 \pm 1.33 \mathrm{a}$ & $73.02 \pm 5.80 \mathrm{a}$ & $1.13 \pm 0.04 \mathrm{a}$ & $87.60 \pm 0.29 \mathrm{a}$ \\
\hline & 180 & $8.31 \pm 0.52 \mathrm{a}$ & $3.82 \pm 0.38 \mathrm{a}$ & $13.28 \pm 2.19 \mathrm{a}$ & $73.11 \pm 7.32 \mathrm{a}$ & $0.95 \pm 0.10 \mathrm{~b}$ & $87.87 \pm 0.52 \mathrm{a}$ \\
\hline \multirow{3}{*}{ Qingzhen 2017} & 120 & $8.36 \pm 0.11 \mathrm{a}$ & $3.27 \pm 0.07 \mathrm{a}$ & $13.47 \pm 2.19 \mathrm{a}$ & $73.07 \pm 8.39 \mathrm{a}$ & $1.26 \pm 0.12 \mathrm{a}$ & $88.37 \pm 0.24 \mathrm{a}$ \\
\hline & 150 & $7.37 \pm 0.71 \mathrm{a}$ & $3.16 \pm 0.26 \mathrm{a}$ & $14.25 \pm 1.16 \mathrm{a}$ & $73.30 \pm 8.62 \mathrm{a}$ & $1.38 \pm 0.02 \mathrm{a}$ & $89.47 \pm 0.31 \mathrm{a}$ \\
\hline & 180 & $8.38 \pm 0.34 \mathrm{a}$ & $3.19 \pm 0.11 \mathrm{a}$ & $14.03 \pm 1.47 \mathrm{a}$ & $72.80 \pm 7.30 \mathrm{a}$ & $1.04 \pm 0.09 \mathrm{~b}$ & $88.43 \pm 0.60 \mathrm{a}$ \\
\hline
\end{tabular}

${ }^{\mathrm{z}}$ Different letters within the column denote significant differences between treatments at $P<0.05$. 
Table 5. Mean fatty acid yields of the tobacco plants under the four $\mathrm{N}$ rates at the two locations.

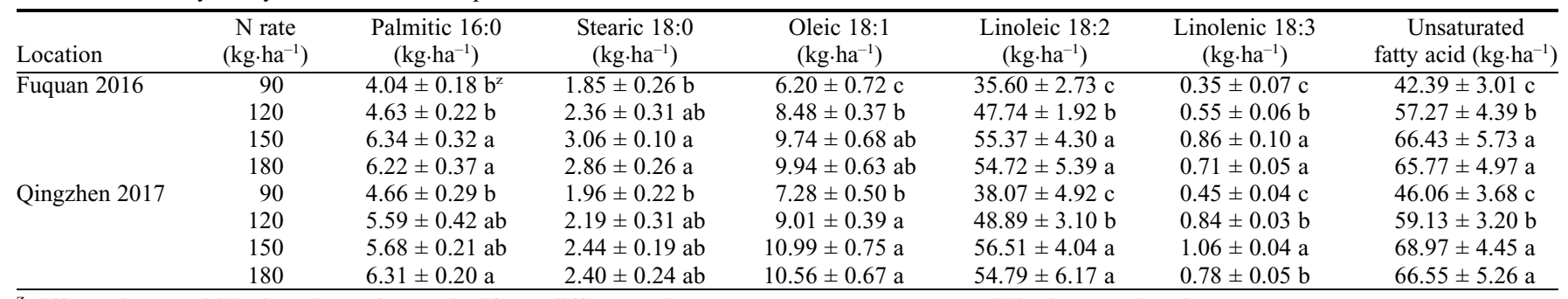

${ }^{\mathrm{z}}$ Different letters within the column denote significant differences between treatments at $P<0.05$ within the same location.

Table 6. Analysis of variance $F$ values for the effects of study sites and $\mathrm{N}$ rates on seed yield, seed oil content, and fatty acidscompositions.

\begin{tabular}{|c|c|c|c|c|c|c|c|c|}
\hline & Seed yield & Seed oil content & Palmitic & Stearic & Oleic & Linoleic & Linolenic & Unsaturated fatty acid \\
\hline $\mathrm{S} \times \mathrm{N}$ & 9.64 & $18.09 *$ & 1.07 & 6.09 & 8.41 & 33.57 & $2.48^{*}$ & 11.32 \\
\hline
\end{tabular}

$*, *$ Significant correlations at the 0.05 and 0.01 levels, respectively.

Table 7. Seed germination potential and germination rate of seeds from tobacco plants grown under different $\mathrm{N}$ rates at the two locations.

\begin{tabular}{lcccc}
\hline & \multicolumn{2}{c}{ Fuquan 2016 } & \multicolumn{2}{c}{ Qingzhen 2017 } \\
\cline { 2 - 4 } N rate $\left(\mathrm{kg} \cdot \mathrm{ha}^{-1}\right)$ & Potential & Rate (\%) & Potential & Rate (\%) \\
\hline 90 & $96.58 \pm 0.22 \mathrm{a}^{z}$ & $97.67 \pm 0.22 \mathrm{a}$ & $94.63 \pm 0.33 \mathrm{a}$ & $95.33 \pm 1.81 \mathrm{a}$ \\
120 & $96.25 \pm 1.18 \mathrm{a}$ & $97.50 \pm 0.90 \mathrm{a}$ & $94.50 \pm 0.85 \mathrm{a}$ & $95.72 \pm 1.22 \mathrm{a}$ \\
150 & $96.92 \pm 0.22 \mathrm{a}$ & $97.67 \pm 0.33 \mathrm{a}$ & $94.82 \pm 0.92 \mathrm{a}$ & $95.48 \pm 1.40 \mathrm{a}$ \\
180 & $96.33 \pm 0.71 \mathrm{a}$ & $97.83 \pm 0.46 \mathrm{a}$ & & $94.72 \pm 0.73 \mathrm{a}$ \\
\hline
\end{tabular}

${ }^{\mathrm{z}}$ Different letters within the column denote significant differences between treatments at $P<0.05$.

Table 8. Morphological traits of the tobacco plants under four $\mathrm{N}$ application rates at the two locations.

\begin{tabular}{lccccc}
\hline Location & N rate $\left({\left.\mathrm{kg} \cdot h \mathrm{~h}^{-1}\right)}\right.$ & Plant $\mathrm{ht}(\mathrm{cm})$ & Stem diam $(\mathrm{cm})$ & Leaf area $\left(\mathrm{cm}^{2}\right)$ & Nodal distance $(\mathrm{cm})$ \\
\hline Fuquan 2016 & 90 & $124.85 \pm 2.17 \mathrm{c}^{\mathrm{z}}$ & $9.58 \pm 0.24 \mathrm{c}$ & $1045.95 \pm 20.27 \mathrm{~b}$ & $4.76 \pm 0.16 \mathrm{c}$ \\
& 120 & $136.81 \pm 4.38 \mathrm{~b}$ & $11.25 \pm 0.25 \mathrm{~b}$ & $1346.03 \pm 37.48 \mathrm{a}$ & $5.00 \pm 0.12 \mathrm{c}$ \\
& 150 & $154.32 \pm 5.32 \mathrm{a}$ & $12.42 \pm 0.16 \mathrm{a}$ & $1471.00 \pm 30.48 \mathrm{a}$ & $6.38 \pm 0.05 \mathrm{a}$ \\
& 180 & $143.37 \pm 3.92 \mathrm{~b}$ & $12.24 \pm 0.10 \mathrm{a}$ & $1447.17 \pm 75.28 \mathrm{a}$ & $4.46 \pm 0.30 \mathrm{a}$ \\
& 90 & $118.08 \pm 2.32 \mathrm{c}$ & $9.37 \pm 0.37 \mathrm{~b}$ & $1092.29 \pm 52.93 \mathrm{~b}$ & $4.30 \pm 0.18 \mathrm{c}$ \\
& 120 & $128.28 \pm 0.51 \mathrm{~b}$ & $10.82 \pm 0.28 \mathrm{a}$ & $1276.73 \pm 28.19 \mathrm{a}$ & $5.72 \pm 0.21 \mathrm{c}$ \\
& 150 & $141.10 \pm 3.21 \mathrm{a}$ & $10.56 \pm 0.31 \mathrm{a}$ & $1324.71 \pm 68.37 \mathrm{a}$ & $6.24 \pm 0.16 \mathrm{~b}$ \\
\hline
\end{tabular}

${ }^{\mathrm{z}}$ Different letters within the column denote significant differences between treatments at $P<0.05$ within the same location.

revealed that increase in the values of the $\mathrm{N}$ application rate had beneficial effects on seed yield, seed oil content, and fatty acid yields (Table 6). These findings combined highlight the critical significance of efficient $\mathrm{N}$ application to high yields of seed oil and individual fatty acids.

The fatty acids found in the triacylglycerol fraction, from the highest content to the lowest, were linoleic, oleic, palmitic, and stearic acids (Tables 4 and 5). Two of these compounds, linoleic and oleic acid, as well as linolenic acid, are the principal components of unsaturated fatty acids, which can be used as an indicator of the nutritional value of seed oils. The consumption of plant-based monounsaturated fats (oleic acid in this study) may help to lower the risk of cardiovascular disease and overall mortality, while polyunsaturated fats (linoleic acid and linolenic acid in this study) help with muscle movement and blood clotting (Tokuyama and Nakamoto, 2011). Moreover, these compounds cannot be synthesized in the human body and must be obtained through the diet; these results indicate that tobacco seed oil has a high nutritional value, even higher than that of some other common edible oils, such as peanut and cottonseed oil (Thakur et al., 1998). In addition, although tobacco seed oil is mostly used as a nonedible oil, it can be used in the drug and cosmetics industry and has been successfully tested as a biodiesel (Giannelos et al., 2002; Usta 2005). Because tobacco seed oil contains various biologically active substances (protein, amino acids, fatty acids, minerals, etc.) and does not contain toxic and unpalatable nicotine, the seed cake remaining after the extraction or cold pressing of tobacco seed oil could potentially also be used in animal nutrition or as a delivery system for edible vaccines to animals (Rossi et al., 2013).

Concerning seed production, nitrogen fertilization seems to be important to ensuring healthy tobacco plants with many flowers and seeds (Grisan et al., 2016), and seed vigor should be considered specifically. Although the high content of unsaturated fatty acids in plant seeds is not conducive to the maintenance of seed vigor as described in corn and cotton (Hoffpauir et al., 1950; Huang et al., 2003), almost no difference was detected in the seed germination potential and germina- tion rate within the same experimental site in a year in the present study (Table 7). This suggests that effective $\mathrm{N}$ management, such as appropriate $\mathrm{N}$ application, only slightly affects the seed germination potential and percentage in terms of seed reproduction and the multiplication of high-quality varieties.

Despite the different climatic conditions, the height and size of the tobacco plants increased significantly with the increase in the $\mathrm{N}$ rate during the 2 years of the experiment in both Fuquan and Qingzhen (Table 8). This would definitely result in an increase in the amount of green tissues (stem and leaves) remaining for biomass production after seed harvest. This biomass, in addition to producing biofuels for transport, substrates for generating electricity and heat, including biogas as described in a previous paragraph (Grisan et al., 2016), can also offer a wide range of alternative applications, such as producing biochar and bio-organic fertilizer (Chen et al., 2015). Thus, the efficient management of $\mathrm{N}$ fertilization in tobacco cultivation is undoubtedly of vital importance for such bioenergy production. 


\section{Conclusion}

This study characterized for the first time the total seed yield, oil content, and fatty acid yields under various $\mathrm{N}$ applications and provided evidence that increasing $\mathrm{N}$ applications increased the total seed yield, oil content and fatty acid yields of seed oil, as well as the residual biomass (stems and leaves) that can be used as a sustainable crop for seed oil, biofuel, and biomass.

\section{Literature Cited}

Andrianov, V., N. Borisjuk, N. Pogrebnyak, A. Brinker, J. Dixon, S. Spitsin, J. Flynn, P. Matyszczuk, K. Andryszak, M. Laurelli, M. Golovkin, and H. Koprowski. 2010. Tobacco as a production platform for biofuel: Overexpression of Arabidopsis DGAT and LEC2 genes increases accumulation and shifts the composition of lipids in green biomass. Plant Biotechnol. J. 8:277-287.

Campiglia, E., R. Mancinelli, and E. Radicetti. 2011. Influence of no-tillage and organic mulching on tomato (Solanum lycopersicum L.) production and nitrogen use in the Mediterranean environment of central Italy. Scientia Hort. 130:588-598.

Chen, Y., W. Chen, Y.C. Lin, J.Z. Cheng, and W.J. Pan. 2015. Effects of biochar on the microecology of tobacco-planting soil and physiology of flue-curd tobacco. Chin. J. Appl. Ecol. 26:3781-3787. (in Chinese).

Cheng, Y., J. Zhao, Z.X. Liu, Z.J. Huo, P. Liu, S.T. Dong, J.W. Zhang, and B. Zhao. 2015. Modified fertilization management of summer maize (Zea mays L.) in northern China improves grain yield and efficiency of nitrogen use. J. Integr. Agr. 14:1644-1657.

Elbadawy, N., E. Hegazi, T. Yehia, M. Abourayya, and T. Mahmoud. 2016. Effect of nitrogen fertilizer on yield, fruit quality and oil content in manzanillo olive trees. J. Arid Land Stud. 26:175-177.

Frega, N., F. Bocci, L.S. Conte, and F. Testa. 1991. Chemical composition of tobacco seeds (Nicotiana tabacum L.). J. Amer. Oil Chem. Soc. 68:29-33.

Gediya, K.M., T.G. Meisheri, and R.P. Kacha. 2008. Seed yield, quality and nutrient uptake by bidi tobacco (Nicotiana tabacum L.) var. A119 as influenced by spacing, nitrogen and phosphorus levels. Res. Crops 9:394-400.

Giannelos, P.N., F. Zannikos, S. Stournas, E. Lois, and G. Anastopoulos. 2002. Tobacco seed oil as an alternative diesel fuel: Physical and chemical properties. Ind. Crops Prod. 16:1-9.

Grisan, S., R. Polizzotto, P. Raiola, S. Cristiani, F. Ventura, F. di Licia, M. Zuin, S. Tommasini, R. Morbidelli, F. Damiani, F. Pupilli, and M. Bellucci. 2016. Alternative use of tobacco as a sustainable crop for seed oil, biofuel, and biomass. Agron. Sustain. Dev. 36:55-62.

Ho, D.P., H.H. Ngo, and W. Guo. 2014. A mini review on renewable sources for biofuel. Bioresour. Technol. 169:742-749.

Hoffpauir, C.L., S.E. Poe, L.U. Wiles, and M. Hicks. 1950. Germination and free fatty acids in seed stock lots of cottonseed. J. Amer. Oil Chem. Soc. 27:347-348.

Huang, X.Y. 2003. Studies on seed vigor and fungicide treatment of high oil and common maize hybrids. Guangxi University.
Jensen, E.S. and H. Hauggaard-Nielsen. 2003. How can increased use of biological N2 fixation in agriculture benefit the environment? Plant Soil 252:177-186.

Kuo, S. and E.J. Jellum. 2002. Influence of winter cover crop and residue management on soil nitrogen availability and corn. Agron. J. 94:501-508.

Li, X., A. Ulfat, S. Shokat, S. Liu, X. Zhu, and F. Liu. 2019. Responses of carbohydrate metabolism enzymes in leaf and spike to $\mathrm{CO}_{2}$ elevation and nitrogen fertilization and their relations to grain yield in wheat. Environ. Exp. Bot. 164:149-156.

Lin, Y.C., W. Chen, Y. Chen, W.C. Gao, F.Z. Ding, H.X. Li, G.L. Liang, and W.J. Pan. 2015. Effects of well-cellar style transplanting on growth and photosynthetic characteristics of flue-cured tobacco seedlings. J. China Agr. Univ. 20:120-126. (in Chinese).

Lin, Y.C., K.S. Wei, W.C. Gao, Y. Chen, Y.C. Lin, W. Chen, H.X. Li, and W.J. Pan. 2018. Effects of plastic mulching film-induced leaf burning on seedling growth in tobacco cultivation: Different findings beyond conservation view. J. Integr. Agr. 17:1327-1337.

Lin, Y.C., L. Yang, M.J. Paul, Y.G. Zu, and Z.H. Tang. 2013. Ethylene promotes germination of Arabidopsis seed under salinity by decreasing reactive oxygen species: Evidence for the involvement of nitric oxide simulated by sodium nitroprusside. Plant Physiol. Biochem. 73:211-218.

Lin, Y.C., J. Zhang, W.C. Gao, Y. Chen, H.X. Li, D.W. Lawlor, M.J. Paul, and W.J. Pan. 2017. Exogenous trehalose improves growth under limiting nitrogen through upregulation of nitrogen metabolism. BMC Plant Biol. 17:247.

Methamem, S., H. Gouta, A. Mougou, M. Mansour, and D. Boujnah. 2015. Yield, fruit and oil content of some olive trees (Olea europaea L.) fieldgrown in Tunisia. Ann. Biol. Res. 6:64-71.

Mohammad, M. and N. Tahir. 2014. Evaluation of chemical compositions of tobacco (Nicotiana tabacum L.) genotypes seeds. Annu. Res. Rev. Biol. 4:1480-1489.

Popova, V., Z. Petkova, T. Ivanova, M. Stoyanova, L. Lazarov, A. Stoyanova, T. Hristeva, M. Docheva, V. Nikolova, N. Nikolov, and V.D. Zheljazkov. 2018. Biologically active components in seeds of three Nicotiana species. Ind. Crops Prod. 117:375-381.

Rossi, L., E. Fusi, G. Baldi, C. Fogher, F. Cheli, A. Baldi, and V. Dell'Orto. 2013. Tobacco seeds by-product as protein source for piglets. Open J. Vet. Med. 3:73-78.

Sainju, U.M. and B.P. Singh. 2008. Nitrogen storage with cover crops and nitrogen fertilization in tilled and nontilled soils. Agron. J. 100:619-627.

Shen, L.X., Y.K. Huang, and T. Li. 2017. Topgrain filling characteristics at an early stage of maize (Zea mays L.) with different nitrogen use efficiencies. J. Integr. Agr. 16:626-639.

Shi, Y. and Z. Yu. 2008. Effects of nitrogen fertilizer rates and ratios of base and topdressing on wheat yield, soil nitrate content and nitrogen balance. Front. Agr. China 2:181-189.

Thakur, L.S., L.J. Parekh, and B.K. Patel. 1998. Evaluation of nutritional quality of tobacco seed oil. Tobacco Res. 2:70-75.

Tokuyama, S. and K. Nakamoto. 2011. Unsaturated fatty acids and pain. Biol. Pharm. Bull. 34:1174-1178.
Usta, N. 2005. Use of tobacco seed oil methyl ester in a turbocharged indirect injection diesel engine. Biomass Bioenergy 28:77-86.

Vanhercke, T., A. El Tahchy, Q. Liu, X.R. Zhou, P. Shrestha, U.K. Divi, J.P. Ral, M.P. Mansour, P.D. Nichols, C.N. James, P.J. Horn, K.D. Chapman, F. Beaudoin, N. Ruiz-López, P.J. Larkin, R.C. de Feyter, S.P. Singh, and J.R. Petrie. 2014. Metabolic engineering of biomass for high energy density: Oilseed-like triacylglycerol yields from plant leaves. Plant Biotechnol. J. 12:231-239.

Verardo, V., Y. Riciputi, G. Sorrenti, P. Ornaghi, B. Marangoni, and M.F. Caboni. 2013. Effect of nitrogen fertilisation rates on the content of fatty acids, sterols, tocopherols and phenolic compounds, and on the oxidative stability of walnuts. Food Sci. Tech. 50:732-738.

Xie, Z., M. Whent, H. Lutterodt, Y. Niu, M. Slavin, R. Kratochvil, and L. Yu. 2011. Phytochemical, antioxidant, and antiproliferative properties of seed oil and flour extracts of Maryland-grown tobacco cultivars. J. Agr. Food Chem. 59:9877-9884.

Xu, H.C., X.L. Dai, J.P. Chu, Y.C. Wang, L.J. Yin, X. Ma, S.X. Dong, and M.R. He. 2018. Integrated management strategy for improving the grain yield and nitrogen-use efficiency of winter wheat. J. Integr. Agr. 17:315-327.

Yong, T.W., P. Chen, Q. Dong, Q. Du, F. Yang, X.C. Wang, W.G. Liu, and W.Y. Yang. 2018. Optimized nitrogen application methods to improve nitrogen use efficiency and nodule nitrogen fixation in a maize-soybean relay intercropping system. J. Integr. Agr. 17:664-676.

Yuan, L. 2020. Clustered ERF transcription factors: Not all created equal. Plant Cell Physiol. 61:1025-1027.

Zhang, H., D.P. Hou, X.L. Peng, B.J. Ma, S.M. Shao, W.J. Jing, J.F. Gu, L.J. Liu, Z.Q. Wang, Y.Y. Liu, and J.C. Yang. 2019. Optimizing integrative cultivation management improves grain quality while increasing yield and nitrogen use efficiency in rice. J. Integr. Agr. 18:2716-2731.

Zhang, M.C., W.X. Sun, Y.Y. Liu, S.G. Luo, J. Zhao, Q. Wu, Z.Y. Wu, and Y. Jiang. 2014. Timing of $\mathrm{N}$ application affects net primary production of soybean with different planting densities. J. Integr. Agr. 13:2778-2787.

Zhang, M.M., B.D. Dong, Y.Z. Qiao, C.H. Shi, H. Yang, Y.K. Wang, and M.Y. Liu. 2018. Yield and water use responses of winter wheat to irrigation and nitrogen application in the North China Plain. J. Integr. Agr. 17:1194-1206.

Zheljazkov, V.D., B.A. Vick, B.S. Baldwin, N. Buehring, T. Astatkie, and B. Johnson. 2009. Oil content and saturated fatty acids in sunflower as a function of planting date, nitrogen, and hybrid. Agron. J. 101:1003-1011.

Zheljazkov, V.D., B.A. Vick, B.S. Baldwin, N. Buehring, C. Coker, T. Astatkie, and B. Johnson. 2011. Oil productivity and composition of sunflower as a function of hybrid and planting date. Ind. Crops Prod. 33:537-543.

Zheljazkov, V.D., B. Vick, M.W. Ebelhar, N. Buehring, and T. Astatkie. 2012. Nitrogenapplications modify seed and oil yields and fatty acid composition of winter mustard. Ind. Crops Prod. 36:28-32.

Zheljazkov, V.D., B. Vick, M.W. Ebelhar, N. Buehring, and T. Astatkie. 2013. Effect of N on yield and chemical profile of winter canola in Mississippi. J. Oleo Sci. 62:453-458. 